A. GOLEBIOWSKI*, S. R. KLOPFENSTEIN, X. SHAO, J. J. CHEN, A.-O. COLSON, A. L. GRIEB, A. F. RUSSELL (PROCTER \& GAMBLE PHARMACEUTICALS, MASON, USA) Solid-Supported Synthesis of a Peptide $\beta$-Turn Mimetic Org. Lett. 2000, 2, 2615-2617.

\section{Solid-State Synthesis of a $\beta$-Turn Mimetic}

Preparation of the isobutylcarbonic acid mixed anhydride of Boc-Phe-OH (1)

Boc-Phe-OH

$\mathrm{N}$-methylmorpholine ( 1.1 equiv)

isobutylchloroformate (1 equiv)

$\mathrm{THF}, 0^{\circ} \mathrm{C}, 15 \mathrm{~min}$

Synthesis

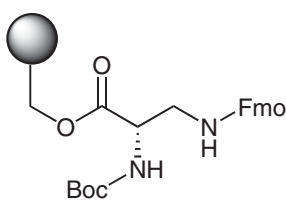

hydrocinnamaldehyde (5 equiv) 2,6-dimethylphenyl isocyanide (5 equiv) (R)-(+)-2-bromopropionic acid (5 equiv)

$\frac{\text { piperidine }}{\mathrm{DMF}, 30 \mathrm{~min}}$

$\mathrm{CHCl}_{3}-\mathrm{MeOH}(4: 1), 2 \mathrm{~h} \times 2$

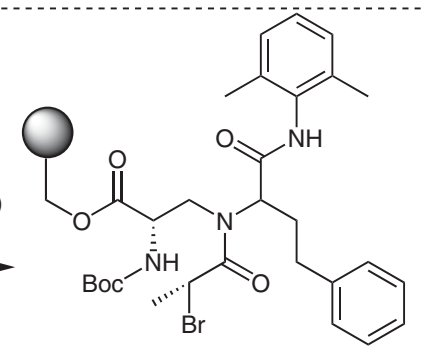

Category

Peptide Chemistry

\section{Key words}

solid-state synthesis

$\beta$-turn

peptide mimetics

Ugi reaction

\section{Synfact}

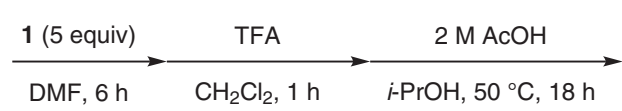

Significance: The $\beta$-turn is one of the most interesting structural peptides and has attracted significant attention not only from biologists, but also from organic chemists. In 2000, the authors have demonstrated the construction of a $\beta$-turn mimetic by solid-supported synthesis.
Comment: Solid-supported synthesis is an effective method for forming peptide bonds. The Ugi reaction was used in the cyclization step to afford the $\beta$-turn mimetic in high yield. 